\title{
Acil Servise Bir Yılda Başvuran Hastalarda Mükerrer Başvuruların İncelenmesi ve Çözüm Önerileri*
}

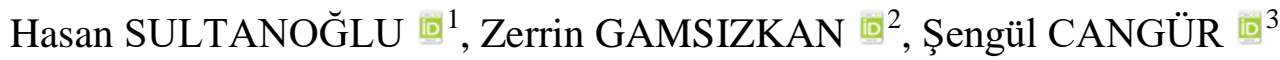

\section{ÖZ}

Amaç: Çalışmamızda acil servise bir yılda başvuran hastalarda mükerrer başvuruların incelenmesi ve çözüm önerilerinin sunulması amaçlanmıştır.

Gereç ve Yöntemler: Acil Servise Ekim 2018-Ekim 2019 tarihleri arasında başvuran hastalara ait veriler retrospektif olarak incelendi. Hastaların sosyodemografik özellikleri, başvuru tanıları, yatış ve konsültasyon bilgileri yanı sıra ilk başvurudan sonraki bir ay içinde tekrar başvuru oranları, yatı̧ durumu, sevk edilme durumu, reçete verilme durumu ve tanıları incelendi.

Bulgular: Bir y1l içinde acil servise 75622 hasta başvurmuş olup \%54,5'i kadın ve $\% 45,5$ 'i erkekti; hastaların yaş ortalaması 40,3 20,2 (0-108) idi. Acil servise gelen hastaların \%17,2'si bir ay içinde bir kez gelen hastalardı. Bir ayda

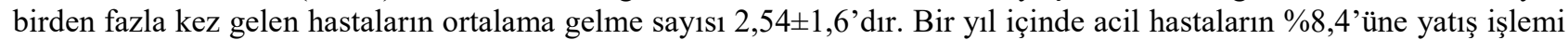
yapılırken, \%0,4'ü sevk edilmiştir. Bir ay içinde tekrar başvuruların \%16,4 yatış yapılmıştır. Bir yıl içinde acil servis birimine gelen hastaların \%53,7'sine reçete yazılmıştır. En sık başvuru tanısı ağrı ve üst solunum yolu enfeksiyonları olarak bulunmuştur.

Sonuç: Sağlık kuruluşlarının en önemli vizyon göstergelerinden biri olan acil sağlık hizmetlerinin verildiği acil servislere tekrar başvuru sayılarını azaltmak için eğitim ile arttırıp sağlık okur yazarlık seviyesini arttırmamız, birinci basamak sistemini etkin kullandırmak, sevk zincirini aktifleştirmek ve acil servis benzeri 7/24 çalışan genel poliklinik sistemi üzerinde çalışmak çözüm önerileri olabilir.

Anahtar Kelimeler: Acil servis; hastanın yeniden başvurusu; toplum sağlı̆̆ eğitimi.

\section{Investigation and Solution Proposals of Repeating Applications in Patients Admitted to the Emergency in a Year}

\begin{abstract}
Aim: The aim of our study is to examine the repeating applications and to offer solution proposals for patients admitted to the emergency department in one year.

Material and Methods: The data of the patients who applied to the Emergency Department between October 2018 and October 2019 were analyzed retrospectively. The patients’ sociodemographic characteristics, application diagnoses, hospitalization and consultation information, as well as re-application rates, hospitalization, referral status, prescribing status and diagnoses were examined within one month after the first application.

Results: Within one year, 75622 patients applied to the emergency department, $54.5 \%$ were women and $45.5 \%$ were men; the average age of the patients was $40.3 \pm 20.2(0-108) .17 .2 \%$ of the patients who came to the emergency room were patients who came once in a month. The average number of arrivals of patients who come more than once in a month is $2.54 \pm 1.6$. While $8.4 \%$ of the emergency patients were hospitalized with in a year, $0.4 \%$ were referred. $16.4 \%$ of admissions were made within one month. Prescriptions were made to $53.7 \%$ of the patients who came to the emergency department within a year. The most common admission diagnosis was pain and upper respiratory tract infections.
\end{abstract}

Conclusions: In order to reduce the number of re-applications to the emergency services where emergency health 
services, which are one of the most important vision indicators of health institutions; Increasing the level of health literacy with education, using the primary care system effectively, activating the referral chain, and working on a 24/7 general polyclinic system like emergency services may be solutions.

Keywords: Emergency department; patient readmission; community health education.

\section{GÍRIS}

Acil Tıp, tüm yaş gruplarındaki hastaları etkileyen ayrıştırılmamış tüm fiziksel ve ruhsal bozuklukların oluşturduğu hastalık ya da yaralanmaların akut ve ivedi şekillerinin önlenmesi, tanısı, tedavisi ve yönetimi için gereken bilgi ve beceriler bütününü kapsayan tıp pratiğini içerir (1).

Sağlık kuruluşlarının en önemli vizyon göstergelerinden biri acil sağlık hizmetlerinin verildiği acil servisler ve bu hizmeti veren acil çalışanlarıdır. Sağlık hizmeti talebinde bulunanların sağlık sorunlarını en yoğun yaşadıkları ve en çok yansıttıkları yerlerin en başında acil servisler gelmektedir (2). Acil servislerin en büyük özelliği kesintisiz hizmet vermeleridir. Bu hizmeti öncelikle en acil olan hastalara hızlı tanı koyarak en kısa süre içinde vermek acil servisin çalışma prensibidir. Günümüzde acil yakınması olmayan hastalar da sıklıkla acil servise başvurmakta ve burada çözüm aramaktadır. Bu hastaların acil servislere başvuruları birçok acil serviste aşırı hasta yoğunluğuna yol açmaktadır. Böylece bekleme süreleri uzayabilmekte, ciddi hastalığı olan hastaların tedavileri gecikmekte, hasta memnuniyetsizliği artmakta, acil serviste genel bir karmaşa ve yetersizlik durumuna yol açmaktadır (3).

Diğer ülkelerde olduğu gibi ülkemizde de acil servis polikliniklerinde engellenemeyen yoğunluk yaşanmakta ve acil servisleri etkin kullanamama sorunu yaşanmaktadır. Hasta yoğunluğunu ve tekrar başvurularını etkileyen faktörler bilimsel olarak açıklanamamakla birlikte Slankamenac ve arkadaşları (4) çalışmalarında tekrar başvuruların acil yoğunluğunu arttırdığına dair veriler elde etmiştir.

Çalışmamızda acil servise bir yılda başvuran hastalarda mükerrer başvuruların incelenmesi ve çözüm önerilerinin sunulması amaçlanmıştır.

\section{GEREÇ VE YÖNTEMLER}

Çalışmamızda Düzce Üniversitesi Araştırma ve Uygulama Hastanesi Acil Servisi'ne Ekim 2018- Ekim 2019 tarihleri arasında başvuran hastalara ait veriler kesitsel ve retrospektif araştırma modeli şeklinde incelendi. Düzce Üniversitesi Etik Kurul onayı oturum ve sayı 2019/185 olacak şekilde, 26.08.2019 tarihinde alındı. Tüm prosedürler kurumsal ve/veya ulusal araştırma komitesinin etik standartlarına ve 2004 Helsinki Bildirgesi'ne uygun olarak yürütüldü.

Hastaların başvuru tanıları, yatış ve konsültasyon bilgileri yanı sıra ilk başvurudan sonraki bir ay içinde tekrar başvuru oranları incelendi. Tanılar International Classification of Diseases-10 (ICD-10) tanı kodlama sistemi kullanılarak sistemlere göre kategorize edildi. Hastalara ait bilgilere hastane otomasyon sistemi ve hasta dosyalarından ulaşıldı. Hastaların sosyodemografik özellikleri (cinsiyet ve yaş), yatış durumu, sevk edilme durumu, reçete verilme durumu ve tanıları incelendi.

\section{İstatistiksel Analiz}

Çalışmada yer alan verilerin türlerine göre uygun tanımlayıcı istatistikler (ortalama, standart sapma, minimum, maksimum, yüzde değerler) hesaplandı. Oran karşılaştırmalarında Binomial ve Chi-square (post hoc: Bonferroni testi) testleri uyguland. Nitel değişkenler arasındaki ilişkilerin değerlendirmesinde Pearson Chisquare ve Fisher-Freeman-Halton testlerinden (post hoc: Bonferroni testi) yararlanıldı. Tüm istatistiksel değerlendirmeler için SPSS 22 programı kullanıldı. $\mathrm{p}<0,05$ istatistiksel olarak anlamlı kabul edildi.

\section{BULGULAR}

Bir yıl içinde acil servise gelen toplam 75622 hastanın \%54,5'i ( $n=41183$ ) kadın ve \%45,5'i (n=34439) erkekti; gelen hastaların yaş ortalaması $40,3 \pm 20,2$ (0-108) idi. Hastaların \%7,1'i (n=5359) 0-18 yaş grubunda, \%92,3'ü $(n=69812)$ 19-89 yaş grubunda ve \%0,6'sı $(n=450)$ ise 90 ve üzeri yaş grubundaydı Acil servise bir yıl içinde gelen kadınların oranı anlamlı düzeyde daha yüksekti $(\mathrm{p}<0,001)$. Ayrıca 19-89 yaş grubundaki bireylerin oranı diğer yaş gruplarındaki bireylerin oranlarından anlamlı düzeyde daha yüksek iken 90 yaş ve üzeri yaş grubundaki bireylerin oranı diğer yaş grubundakilerin oranlarından anlamlı düzeyde daha düşüktü (her biri için $\mathrm{p}<0,01$, Tablo 1).

Tablo 1.Bir yıl içinde acil servise gelen hastaların özelliklerine göre dağılımları

\begin{tabular}{|c|c|c|c|c|}
\hline \multicolumn{2}{|c|}{ Hastaların özellikleri } & \multirow{3}{*}{\begin{tabular}{|c|}
$\mathbf{n}$ \\
41183 \\
34439
\end{tabular}} & \multirow{3}{*}{\begin{tabular}{|c|}
$\%$ \\
54,5 \\
45,5 \\
\end{tabular}} & \multirow{3}{*}{$\frac{\mathbf{p}}{<\mathbf{0 , 0 0}}$} \\
\hline \multirow{2}{*}{ Cinsiyet } & Kadın & & & \\
\hline & Erkek & & & \\
\hline \multirow{3}{*}{ Yaş grubu } & 0-18 & 5359 & 7,1 & \multirow{3}{*}{$<0,001$} \\
\hline & 19-89 & 69812 & 92,3 & \\
\hline & $90-+$ & 450 & 0,6 & \\
\hline \multirow{2}{*}{$\begin{array}{l}\text { Biray içinde } \\
\text { tekrar gelme } \\
\text { durumu }\end{array}$} & Hayır & 62620 & 82,8 & \multirow[b]{2}{*}{$<0,001$} \\
\hline & Evet & 13002 & 17,2 & \\
\hline \multirow{7}{*}{ Acil Birimi } & Aile Hekimliği & 1155 & 1,5 & \multirow{7}{*}{$<0,001$} \\
\hline & Dahiliye & 14479 & 19,1 & \\
\hline & Erișkin & 47917 & 63,4 & \\
\hline & Genel Cerrahi & 6910 & 9,1 & \\
\hline & $\begin{array}{c}\text { Göğüus } \\
\text { Hastalıkları }\end{array}$ & 134 & 0,2 & \\
\hline & Kadın Doğum & 272 & 0,4 & \\
\hline & Ortopedi & 4755 & 6,3 & \\
\hline \multirow{2}{*}{$\begin{array}{l}\text { Yatış } \\
\text { durumu }\end{array}$} & Yatmamış & 69304 & 91,6 & \multirow{2}{*}{$<\mathbf{0 , 0 0 1}$} \\
\hline & Yatmış & 6318 & 8,4 & \\
\hline \multirow{2}{*}{$\begin{array}{l}\text { Reçete } \\
\text { verilme } \\
\text { durumu }\end{array}$} & Yok & 34995 & 46,3 & \multirow[b]{2}{*}{$<0,001$} \\
\hline & Var & 40627 & 53,7 & \\
\hline \multirow{2}{*}{$\begin{array}{l}\text { Sevk edilme } \\
\text { durumu }\end{array}$} & Sevk edilmemiş & 75301 & 99,6 & \multirow{2}{*}{$<0,001$} \\
\hline & Sevk edilmiş & 321 & 0,4 & \\
\hline
\end{tabular}

Acil servise gelen hastaların \%17,2'si $(n=13002)$ bir ay içinde bir kez gelen hastalardı. Bir ay içinde acil servise tekrar gelen ve gelmeyen hastaların oranları farklı $(\mathrm{p}<0,001)$ ve bir ay içinde acil servise tekrar gelen hastaların oranı anlamlı düzeyde yüksekti. Ayrıca bir ayda birden fazla kez gelen hastaların ortalama gelme sayıs1 2,54 $\pm 1,6$ (2-24)'dır (Tablo 1). 
Bir yıl içinde acil servis birimine gelen hastaların \%8,4'üne $(\mathrm{n}=6318)$ yatış işlemi yapılırken \%91,6'sına $(n=69304)$ yatış işlemi yapılmamıştı. Bir yıl içinde acil servis birimine gelen hastaların yatış durumuna ait oran dağılımı arasında anlamlı düzeyde fark vardı $(\mathrm{p}<0,001)$ (Tablo 1).

Bir yıl içinde acil servis birimine gelen hastaların \%53,7'sine $(n=40627)$ reçete yazılırken \%46,3'üne $(n=34995)$ reçete yazılmamıştı. Bir yıl içinde acil servis birimine gelen hastaların reçete yazılma durumuna ait oran dağılımı arasında anlamlı düzeyde fark vardı ( $<<0,001)$ (Tablo 1).

Bir yıl içinde acil servis birimine gelen hastaların \%0,4'ü $(n=321) \quad$ sevk edilirken \%99,6's1 (n=75301) sevk edilmemişti. Bir yıl içinde acil servis birimine gelen hastaların sevk edilme durumuna ait oran dağılımı arasında anlamlı düzeyde fark vardı $(\mathrm{p}<0,001)$ (Tablo 1). Acil servis birimine gelen hastalara en fazla koyulan ilk 10 tanı \%12,7 ile R52 (Akut ağr1), \%9,3 ile Z00 (Genel tıbbi muayene), \%9,1 ile R07 (Boğaz ağrıs1), \%5,8ile J06 (Akut Üst Solunum Yolu Enfeksiyonu), \%5,5 ile R10 (Karın Ağrısı), \%5,2 ile J39(Akut Akciğer Enfeksiyonu), \%4,5 ile M79 (Miyalji), \%4,4 ile T79 (Travma), \%3,3 ile Z33 (Gebelik), \%3,3 ile R05 (Öksürük)’tü (Tablo 2).

Tablo 2. Bir yıl içinde acil servise gelen hastaların ilk 10 $\tan 1$

\begin{tabular}{|c|l|c|c|}
\hline Tanı kodu & Tanı & $\mathbf{n}$ & $\mathbf{\%}$ \\
\hline R52 & Ağrı & 9624 & 12,7 \\
\hline Z00 & Genel tıbbi muayene & 7021 & 9,3 \\
\hline R07 & Boğaz ağrısı & 6896 & 9,1 \\
\hline J06 & $\begin{array}{l}\text { Akut üst solunum yolu } \\
\text { enfeksiyonu }\end{array}$ & 4366 & 5,8 \\
\hline R10 & Karın ağrısı & 4122 & 5,5 \\
\hline J39 & $\begin{array}{l}\text { Üst solunum yolu } \\
\text { enfeksiyonu }\end{array}$ & 3962 & 5,2 \\
\hline M79 & $\begin{array}{l}\text { Yumuşak doku } \\
\text { bozukluğu }\end{array}$ & 3396 & 4,5 \\
\hline T79 & $\begin{array}{l}\text { Travmanın bazı erken } \\
\text { komplikasyonları }\end{array}$ & 3336 & 4,4 \\
\hline Z33 & Gebelik durumu & 2520 & 3,3 \\
\hline R05 & Öksürük & 2472 & 3,3 \\
\hline
\end{tabular}

Hastaların yatış yaptıkları uzmanlık dallarına ait oranlar anlamlı düzeyde birbirinden farklıydı $(\mathrm{p}<0,001)$. Bir yıl içinde en fazla yatış yapılan ilk üç uzmanlık dalı \%21,7 $(n=1372)$ ile Kadın Hastalıkları ve Doğum, \%20 ( $n=1263)$ ile Kardiyoloji ve \%11,2 ( $n=708)$ ile Ortopedi ve Travmatoloji iken en az müracaat edilen üç uzmanlık dalı 1'er hasta ile T1bbi Onkoloji, Gastroenteroloji ve Çocuk Endokrinolojisiydi (Tablo 3).

Hastaların sevk edildikleri uzmanlık dallarına ait oranlar anlamlı düzeyde birbirinden farklıydı $(\mathrm{p}<0,001)$. Bir y1 içinde en fazla sevk edilen ilk üç uzmanlık dalı \%51,4 ( $n=165)$ ile Anesteziyoloji ve Reanimasyon, \%10 ( $n=32)$ ile Kardiyoloji ve \%9,3 $(n=30)$ ile Kalp ve Damar Cerrahisi iken en az sevk edilen uzmanlık dalları 1'er hasta ile Çocuk Cerrahisi, Çocuk Sağlığı ve Hastalıkları, Çocuk ve Ergen Ruh Sağlığı ve Hastalıkları, Diğer Uzmanlıklar, Gastroenteroloji, Göz Hastalıkları ve Radyoloji idi (Tablo 4).
Tablo 3.Bir yıl içinde acil servise gelen hastaların yatış yaptıkları uzmanlık alanlarına göre dağılımı

\begin{tabular}{|l|c|c|}
\hline Yatılan Uzmanlık Alanı & $\mathbf{n}$ & $\mathbf{\%}$ \\
\hline Anesteziyoloji ve Reanimasyon & 95 & 1,5 \\
\hline Beyin ve Sinir Cerrahisi & 239 & 3,8 \\
\hline Çocuk Cerrahisi & 14 & 0,2 \\
\hline Çocuk Endokrinolojisi & 1 & 0 \\
\hline Çocuk Sağlığı ve Hastalıkları & 4 & 0,1 \\
\hline Deri ve Zührevi Hastalıkları & 6 & 0,1 \\
\hline $\begin{array}{l}\text { Enfeksiyon Hastalıkları ve Klinik } \\
\text { Mikrobiyoloji }\end{array}$ & 84 & 1,3 \\
\hline Fiziksel Tıp ve Rehabilitasyon & 29 & 0,5 \\
\hline Gastroenteroloji & 1 & 0 \\
\hline Genel Cerrahi & 701 & 11,1 \\
\hline Göğüs Cerrahisi & 34 & 0,5 \\
\hline Göğ̈̈s Hastalıkları & 368 & 5,8 \\
\hline Göz Hastalıkları & 17 & 0,3 \\
\hline Hematoloji & 3 & 0 \\
\hline İç Hastalıkları & 736 & 11,6 \\
\hline Kadın Hastalıkları ve Doğum & 1372 & 21,7 \\
\hline Kalp ve Damar Cerrahisi & 28 & 0,4 \\
\hline Kardiyoloji & 1263 & 20 \\
\hline Kulak-Burun-Boğaz Hastalıkları & 186 & 2,9 \\
\hline Nefroloji & 5 & 0,1 \\
\hline Nöroloji & 315 & 5 \\
\hline Ortopedi ve Travmatoloji & 708 & 11,2 \\
\hline Ruh Sağlığı ve Hastalıkları & 28 & 0,4 \\
\hline Tıbbi Onkoloji & 1 & 0 \\
\hline Üroloji & 80 & 1,3 \\
\hline Toplam & 6318 & 100 \\
\hline
\end{tabular}

Tablo 4. Bir yıl içinde acil servise gelen hastaların sevk edildikleri uzmanlık dallarına göre dağılımı

\begin{tabular}{|l|c|c|}
\hline Sevk Edilen Uzmanlık Dalı & n & $\mathbf{\%}$ \\
\hline Acil Tıp & 4 & 1,2 \\
\hline Anesteziyoloji ve Reanimasyon & 165 & 51,4 \\
\hline Beyin ve Sinir Cerrahisi & 13 & 4,0 \\
\hline Çocuk Cerrahisi & 1 & 0,3 \\
\hline Çocuk Sağlığı ve Hastalıkları & 1 & 0,3 \\
\hline Çocuk ve Ergen Ruh Sağlığı ve Hastalıkları & 1 & 0,3 \\
\hline Diğer Uzmanlıklar & 1 & 0,3 \\
\hline $\begin{array}{l}\text { Enfeksiyon Hastalıkları ve Klinik } \\
\text { Mikrobiyoloji }\end{array}$ & 2 & 0,6 \\
\hline Gastroenteroloji & 1 & 0,3 \\
\hline Genel Cerrahi & 5 & 1,6 \\
\hline Göğüs Cerrahisi & 4 & 1,2 \\
\hline Göğüs Hastalıkları & 3 & 0,9 \\
\hline Göz Hastalıkları & 1 & 0,3 \\
\hline İc Hastalıkları & 10 & 3,1 \\
\hline Kadın Hastalıkları ve Doğum & 4 & 1,2 \\
\hline Kalp ve Damar Cerrahisi & 30 & 9,3 \\
\hline Kardiyoloji & 32 & 10 \\
\hline Nefroloji & 2 & 0,6 \\
\hline Nöroloji & 6 & 1,9 \\
\hline Ortopedi ve Travmatoloji & 5 & 1,6 \\
\hline Plastik, Rekonstrüktif ve Estetik Cerrahi & 8 & 2,5 \\
\hline Radyoloji & 1 & 0,3 \\
\hline Ruh Sağlı̆̆ı ve Hastalıkları & 13 & 4 \\
\hline Yoğun Bakım (İç Hastalıkları) & 8 & 2,5 \\
\hline Toplam & 321 & 100 \\
\hline
\end{tabular}


Tablo 5.Bir ay içinde acil servise tekrar gelme durumuna göre hastaların özelliklerinin oran dağılımları

\begin{tabular}{|c|c|c|c|c|c|c|c|c|}
\hline \multirow{2}{*}{\multicolumn{2}{|c|}{ Hastanın Özellikleri }} & \multicolumn{2}{|c|}{ Hayır } & \multicolumn{2}{|c|}{ Evet } & \multicolumn{2}{|c|}{ Toplam } & \multirow[b]{2}{*}{ p } \\
\hline & & \multirow{2}{*}{$\begin{array}{c}\mathbf{n} \\
33980 \\
\end{array}$} & \multirow{2}{*}{$\begin{array}{c}\% \\
82,5 \\
\end{array}$} & \multirow{2}{*}{$\begin{array}{c}\mathbf{n} \\
7203 \\
\end{array}$} & \multirow{2}{*}{$\begin{array}{c}\mathbf{\%} \\
17,5\end{array}$} & \multirow{2}{*}{$\begin{array}{c}\mathbf{n} \\
41183 \\
\end{array}$} & \multirow{2}{*}{$\begin{array}{c}\% \\
100 \\
\end{array}$} & \\
\hline Cinsiyet & Kadın & & & & & & & \multirow{2}{*}{0,018} \\
\hline & Erkek & 28640 & 83,2 & 5799 & 16,8 & 34439 & 100 & \\
\hline \multirow[t]{3}{*}{ Yaş grubu } & $0-18$ & 4807 & 89,7 & 552 & 10,3 & 5359 & 100 & \multirow{3}{*}{$<0,001$} \\
\hline & 19-89 & 57448 & 92,3 & 12364 & 17,7 & 69812 & 100 & \\
\hline & 90-+ & 364 & 80,9 & 86 & 19,1 & 450 & 100 & \\
\hline Acil Birimi & Acil Poliklinik & 62620 & 82,8 & 13002 & 17,2 & 75622 & 100 & $<0,001$ \\
\hline \multirow[t]{2}{*}{ Yatış durumu } & Yatmamış & 57339 & 82,7 & 11965 & 17,3 & 69304 & 100 & \multirow[t]{2}{*}{0,086} \\
\hline & Yatmış & 5281 & 83,6 & 1037 & 16,4 & 6318 & 100 & \\
\hline \multirow{2}{*}{$\begin{array}{l}\text { Reçete verilme } \\
\text { durumu }\end{array}$} & Yok & 29699 & 84,9 & 5296 & 15,1 & 34995 & 100 & \multirow[t]{2}{*}{$<0,001$} \\
\hline & Var & 32921 & 81 & 7706 & 19 & 40627 & 100 & \\
\hline \multirow{2}{*}{$\begin{array}{l}\text { Sevk edilme } \\
\text { durumu }\end{array}$} & Sevk edilmemiş & 62340 & 82,8 & 12961 & 17,2 & 75301 & 100 & \multirow[t]{2}{*}{0,035} \\
\hline & Sevk edilmiş & 280 & 87,2 & 41 & 12,8 & 321 & 100 & \\
\hline
\end{tabular}

Cinsiyete göre bir ay içinde acil servise tekrar gelme durumuna ait oranlar arasında anlamlı düzeyde fark vardı $(\mathrm{p}=0,018)$. Kadın hastalardan bir ay içinde acil servise tekrar gelenlerin oranı \%17,5 iken erkek hastaların oranı $\% 16,8$ 'di. Yaş gruplarına göre bir ay içinde acil servise tekrar gelme durumuna ait oranlar arasinda anlaml düzeyde fark vardı $(\mathrm{p}<0,001) .0-18$ yaş grubundaki bir ay içinde tekrar gelen hastaların oranı \%10,3, 19-89 yaş grubu \%17,7 ve “90 ve üzeri” yaş grubunda ise \%19,1'dir $(p<0,05)$. Bir ay içinde acil servise tekrar gelme durumuna göre hastaların yatış durumuna ait oranlar arasında anlamlı düzeyde bir fark saptanmadı $(p=0,086)$. Bir ay içinde acil servise tekrar gelme durumuna göre reçete yazılan ve yazılmayan hastaların oran dağılımları arasında anlamlı düzeyde fark vardı $(\mathrm{p}<0,001)$. Bir ay içinde acil servise tekrar gelen ve reçete yazılan hastaların oranı \%59,3 iken, tekrar gelmeyen ve reçete yazılan hastaların oranı $\% 52,6$ olup anlamlı düzeyde daha yüksekti $(\mathrm{p}<0,05)$.Ayrıca reçete yazılan ve bir ay içinde acil servise tekrar gelen hastaların oranı (\%19), reçete yazılmayan ve bir ay içinde acil servise tekrar gelen hastaların oranı \%15,1 olup anlamlı düzeyde daha yüksekti $(\mathrm{p}<0,05)$. Bir ay içinde acil servise tekrar gelme durumuna göre hastaların sevk edilme durumuna ait oranlar anlamlı düzeyde birbirinden farklıydı $(\mathrm{p}=0,035)$. Bir ay içinde acil servise tekrar gelen ve sevk edilen hastaların oranı $(\% 0,3)$, bir ay içinde acil servise tekrar gelmeyen ve sevk edilen hastaların oranı $(\% 0,4)$ anlaml düzeyde daha düşüktü $(\mathrm{p}<0,05)$. Ayrıca sevk edilen ve bir ay içinde acil servise tekrar gelen hastaların oranı $(\% 12,8)$, sevk edilmeyen ve bir ay içinde acil servise tekrar gelen hastaların oranından $(\% 17,2)$ anlamlı düzeyde daha düşüktü $(\mathrm{p}<0,05$ Tablo 5).

Bir ay içinde acil servise tekrar gelme durumuna göre yatış yapılan uzmanlık dallarının oranları arasında anlamlı düzeyde fark vardı ( $\mathrm{p}<0,001$ Tablo 6).

Bir ay içinde acil servise tekrar gelme durumuna göre sevk edilen uzmanlık dallarının oranları Tablo 7'de verilmiştir.
Tablo 6. Bir ay içinde acil servise tekrar gelme durumuna göre yatış yapılan uzmanlık dallarının oran dağılımları

\begin{tabular}{|l|c|c|c|c|c|c|}
\hline \multirow{2}{*}{$\begin{array}{l}\text { Yatıs Yapılan Uzmanlık } \\
\text { Dalı }\end{array}$} & \multicolumn{2}{|c|}{ Hayır } & \multicolumn{2}{c|}{ Evet } & \multicolumn{2}{c|}{ Toplam } \\
\cline { 2 - 7 } & $\mathbf{n}$ & $\mathbf{\%}$ & $\mathbf{n}$ & $\mathbf{\%}$ & $\mathbf{n}$ & $\mathbf{\%}$ \\
\hline $\begin{array}{l}\text { Anesteziyoloji ve } \\
\text { Reanimasyon }\end{array}$ & 87 & 91,6 & 8 & 8,4 & 95 & 100 \\
\hline Beyin ve Sinir Cerrahisi & 204 & 85,4 & 35 & 14,6 & 239 & 100 \\
\hline Çocuk Cerrahisi & 13 & 92,9 & 1 & 7,1 & 14 & 100 \\
\hline Çocuk Endokrinolojisi & 1 & 100 & 0 & - & 1 & 100 \\
\hline $\begin{array}{l}\text { Cocuk Sağlı̆ı ve } \\
\text { Hastalıkları }\end{array}$ & 3 & 75 & 1 & 25 & 4 & 100 \\
\hline Deri ve Zührevi Hastalıkları & 6 & 100 & 0 & - & 6 & 100 \\
\hline $\begin{array}{l}\text { Enfeksiyon Hastalıkları ve } \\
\text { Klinik Mikrobiyoloji }\end{array}$ & 69 & 82,1 & 15 & 17,9 & 84 & 100 \\
\hline $\begin{array}{l}\text { Fiziksel Tıp ve } \\
\text { Rehabilitasyon }\end{array}$ & 29 & 100 & 0 & - & 29 & 100 \\
\hline Gastroenteroloji & 1 & 100 & 0 & - & 1 & 100 \\
\hline Genel Cerrahi & 572 & 81,6 & 129 & 18,4 & 701 & 100 \\
\hline Göğüs Cerrahisi & 24 & 70,6 & 10 & 29,4 & 34 & 100 \\
\hline Göğüs Hastalıkları & 298 & 81 & 70 & 19 & 368 & 100 \\
\hline Göz Hastalıkları & 15 & 88,2 & 2 & 11,8 & 17 & 100 \\
\hline Hematoloji & 3 & 100 & 0 & - & 3 & 100 \\
\hline İç Hastalıkları & 627 & 85,2 & 109 & 14,8 & 736 & 100 \\
\hline $\begin{array}{l}\text { Kadın Hastalıkları ve } \\
\text { Doğum }\end{array}$ & 1125 & 82 & 247 & 18 & 1372 & 100 \\
\hline Kalp ve Damar Cerrahisi & 22 & 78,6 & 6 & 21,4 & 28 & 100 \\
\hline Kardiyoloji & 1085 & 85,9 & 178 & 14,1 & 1263 & 100 \\
\hline $\begin{array}{l}\text { Kulak-Burun-Boğaz } \\
\text { Hastalıkları }\end{array}$ & 174 & 93,5 & 12 & 6,5 & 186 & 100 \\
\hline Nefroloji & 5 & 100 & 0 & - & 5 & 100 \\
\hline Nöroloji & 567 & 81,3 & 59 & 18,7 & 315 & 100 \\
\hline Ortopedi ve Travmatoloji & 50,1 & 141 & 19,9 & 708 & 100 \\
\hline Ruh Sağlı̆ğ ve Hastalıkları & 27 & 96,4 & 1 & 3,6 & 28 & 100 \\
\hline Tıbbi Onkoloji & 1 & 100 & 0 & - & 1 & 100 \\
\hline Üroloji & 67 & 83,8 & 13 & 16,3 & 80 & 100 \\
\hline Toplam & 5281 & 83,6 & 1037 & 16,4 & 6318 & 100 \\
\hline
\end{tabular}


Tablo 7. Bir ay içinde acil servise tekrar gelme durumuna göre sevk edilen uzmanlık dallarının oran dağılımları

\begin{tabular}{|l|c|c|c|c|c|c|}
\hline \multirow{2}{*}{$\begin{array}{l}\text { Sevk Edilen Uzmanlık } \\
\text { Dalı }\end{array}$} & \multicolumn{2}{|c|}{ Hayır } & \multicolumn{2}{|c|}{ Evet } & \multicolumn{2}{c|}{ Toplam } \\
\cline { 2 - 7 } & $\mathbf{n}$ & $\mathbf{\%}$ & $\mathbf{n}$ & $\mathbf{\%}$ & $\mathbf{n}$ & $\mathbf{\%}$ \\
\hline Acil Tıp & 3 & 75 & 1 & 25 & 4 & 100 \\
\hline $\begin{array}{l}\text { Anesteziyoloji ve } \\
\text { Reanimasyon }\end{array}$ & 146 & 88,5 & 19 & 11,5 & 165 & 100 \\
\hline Beyin ve Sinir Cerrahisi & 10 & 76,9 & 3 & 23,1 & 13 & 100 \\
\hline Çocuk Cerrahisi & 1 & 100 & 0 & - & 1 & 100 \\
\hline $\begin{array}{l}\text { Çocuk Sağlığı ve } \\
\text { Hastalıkları }\end{array}$ & 1 & 100 & 0 & - & 1 & 100 \\
\hline $\begin{array}{l}\text { Çocuk ve Ergen Ruh } \\
\text { Sağlı̆̆ ve Hastalıkları }\end{array}$ & 1 & 100 & 0 & - & 1 & 100 \\
\hline Diğer Uzmanlıklar & 1 & 100 & 0 & - & 1 & 100 \\
\hline $\begin{array}{l}\text { Enfeksiyon Hastalıkları } \\
\text { ve Klinik Mikrobiyoloji }\end{array}$ & 2 & 100 & 0 & - & 2 & 100 \\
\hline Gastroenteroloji & 1 & 100 & 0 & - & 1 & 100 \\
\hline Genel Cerrahi & 4 & 80 & 1 & 20 & 5 & 100 \\
\hline Göğüs Cerrahisi & 3 & 75 & 1 & 25 & 4 & 100 \\
\hline Göğüs Hastalıkları & 0 & - & 3 & 100 & 3 & 100 \\
\hline Göz Hastalıkları & 1 & 100 & 0 & - & 1 & 100 \\
\hline İç Hastalıkları & 10 & 100 & 0 & - & 10 & 100 \\
\hline $\begin{array}{l}\text { Kadın Hastalıkları ve } \\
\text { Doğum }\end{array}$ & 4 & 100 & 0 & - & 4 & 100 \\
\hline $\begin{array}{l}\text { Kalp ve Damar } \\
\text { Cerrahisi }\end{array}$ & 26 & 86,7 & 4 & 13,3 & 30 & 100 \\
\hline Kardiyoloji & 28 & 87,5 & 4 & 12,5 & 32 & 100 \\
\hline Nefroloji & 1 & 50 & 1 & 50 & 2 & 100 \\
\hline Nöroloji & 6 & 100 & 0 & - & 6 & 100 \\
\hline $\begin{array}{l}\text { Ortopedi ve } \\
\text { Travmatoloji }\end{array}$ & 100 & 0 & - & 5 & 100 \\
\hline $\begin{array}{l}\text { Plastik, Rekonstrüktif } \\
\text { ve Estetik Cerrahi }\end{array}$ & 5 & 62,5 & 3 & 37,5 & 8 & 100 \\
\hline Radyoloji & 1 & 100 & 0 & - & 1 & 100 \\
\hline $\begin{array}{l}\text { Ruh Sağlığı ve } \\
\text { Hastalıkları }\end{array}$ & 92,3 & 1 & 7,7 & 13 & 100 \\
\hline $\begin{array}{l}\text { Yoğun Bakım (İç } \\
\text { Hastalıkları) }\end{array}$ & 100 & 0 & - & 8 & 100 \\
\hline Toplam & 87,2 & 41 & 12,8 & 321 & 100 \\
\hline
\end{tabular}

\section{TARTIŞMA}

Acil servisler sağlık kuruluşlarının en önemli vizyon göstergesidir, bu vizyonu acil çalışanları yanı sıra verilen hizmetin kalitesi, başvuran hasta sayısı ve hastalıkların nitelikleri belirler. Ülkemizde daha fazla olmak üzere diğer ülkelerde olduğu gibi acil servis polikliniklerinde engellenemeyen yoğunluk yaşanmakta ve acil servisleri etkin kullanamama sorunu yaşanmaktadır. Çalışmamızda acil servise bir yılda başvuran hastalarda tekrar başvurularının incelenmesi ve çözüm önerilerinin sunulması amaçlanmıştı.

Hastaların bir yıl içerisinde \%54,5'i kadın ve \%45,5'i erkekti; kadınların oranı anlamlı düzeyde daha yüksekti $(\mathrm{p}<0,001)$. Kadın hastalardan bir ay içinde acil servise tekrar gelenlerin oranı \% 17,5 iken erkek hastaların oranı \%16,8'di. Birçok çalışmada bizim çalışmamıza benzer şekilde kadın oranı yüksek çıkmıştır $(5,6)$. 19-89 yaş grubu hastaların \%92,3'ü olup bu yaş grubundaki bireylerin oranı diğer yaş gruplarındaki bireylerin oranlarından anlamlı düzeyde daha yüksekti ve bu sonuç literatürle uyumlu saptanmıştır (7). Yaş gruplarına göre bir ay içinde acil servise tekrar gelme durumuna ait oranlar arasında anlamlı düzeyde fark vardı $(\mathrm{p}<0,001)$. 0 18 yaş grubundaki bir ay içinde tekrar gelen hastaların oranı $\% 10,3 ; 19-89$ yaş grubu \%17,7 ve "90 ve üzeri” yaş grubunda ise \%19,1 idi $(\mathrm{p}<0,05)$. Literatürde birçok çalışmada çalışmamızda olduğu gibi tekrar başvuruların sık olduğu tespit edilmiştir $(5,7,8)$.

Sosyoekonomik ve sosyokültürel düzeylerin farklılığ 1 tekrar başvuruların en sık nedenidir; hemen tedavi olma isteği, daha hızlı tetkik ve sonuç elde edilmesi, mesai saatlerinin uyumsuzluğu, hangi polikliniğge gideceğini bilememek başvuruları arttırmaktadır. Bir yıl içinde acil servis birimine gelen hastaların \%53,7'sine reçete yazılmıştır. Bir ay içinde acil servise tekrar gelme durumuna göre reçete yazılan ve yazılmayan hastaların oran dağılımları arasında anlamlı düzeyde fark vardı $(p<0,001)$. Bir ay içinde acil servise tekrar gelen ve reçete yazılan hastaların oranı \%59,3 $(\mathrm{p}<0,05)$. Bununla ilgili çalışma yapılmamış olup birinci basamak ve poliklinikte yazılabilecek, acil reçetesi dışında yazılan reçetelerin tekrar başvuruyu arttıran etken olduğunu düşünmekteyiz. Bir ay içinde acil servise tekrar gelme durumuna göre hastaların yatış durumuna ait oranlar arasında anlamlı düzeyde bir fark saptanmadı $(\mathrm{p}=0,086)$. Bir y1l içinde acil servise başvuran hastaların \%8,4'üne $(n=6318)$ yatış işlemi yapılmıştır. Bir yıl içinde acil servis birimine gelen hastaların yatış durumuna ait oran dağılımı arasında anlamlı düzeyde fark vardı $(\mathrm{p}<0,001)$. Literatürde acil servisten yatış oranları \%4-13 arasında değişmektedir, çalışmamız literatürle uyumlu saptanmıştır $(5,7)$.

Bir yıl içinde acil servis birimine gelen hastaların \%0,4'ü sevk edilmiştir. Bir ay içinde acil servise tekrar gelme durumuna göre hastaların sevk edilme durumuna ait oranlar anlamlı düzeyde birbirinden farklıydı $(\mathrm{p}=0,035)$. Literatürde sevk oranları \%3-5 arasında değişmekte olup, çalışmamızdan farklı saptanmıştır $(7,9)$. Bu farklılığın 3.basamak hastane olmamız ve çalışmamızın yapıldı ̆̆ Düzce'de başka 3. basamak hastane olmamasından kaynakladığını düşünmekteyiz.

Acil servis birimine gelen hastalara en fazla konulan tan akut ağrı ve üst solunum yollarını ilgilendiren tanılar olup literatürdeki çalışmalarla uyumlu saptanmıştır $(10,11)$.

Hastaların yatış yaptıkları uzmanlık dallarına ait oranlar anlamlı düzeyde birbirinden farklıyd. En fazla Kadın Hastalıkları ve Doğum, Kardiyoloji, Ortopedi ve Travmatoloji'ye yatış yapılmıştır. Literatürdeki yatış yapılan uzmanlık dallarının oranları ile ilgili farklı sonuçlar bildirilmiştir (7,12). Bunun nedeni hastanelerdeki yatış endikasyonlarına yaklaşımın farklı olması, ilin demografik yapısının değişkenliği ve hastanelerin özgün işleyişi olabilir.

Tekrar başvuru sıklığı azaltmada sağlık okuryazarlığı arttırmanın etkili olacağını düşünmekteyiz. Eğitim düzeyi arttıkça sağlık okuryazarlığı puanın da arttığı, eğitim düzeyi düşük olan kişilerin genel sağlık düzeyinin de kötü olduğu, bu kişilerin daha çok hastalandığı ve daha çok hastaneye başvurduğu tespit edilmiş olup sağlık bilincinin artırılması gerekmektedir (13).

Günümüzde yaşam süresinin uzaması ile birlikte kronik hastalıkların artışı acil başvuruların sık olmasının nedenleri arasındadır. Hastane yatışlarını azaltmak için hedeflenecek en etkili iki alanın birinci basamak takip randevu sistemi ve sağlık sigortası olduğu görülmektedir (14). Hastalar polikliniklerden randevu alamama veya hasta yoğunluğundan kaynaklanan geç tarihli randevu alma gibi nedenlerden dolayı acil servise yönelmektedir. 
Acil servis yoğunluğunu ve tekrarlayan başvuruları arttıran bu faktörlere yönelik çalışmaların yapılmasının gerekli olduğunu düşünmekteyiz.

\section{SONUÇ}

Sonuç olarak sağlık konusunda bilgi yetersizliği sağlık harcamalarının artmasına yol açmaktadır. Eğitim seviyesinin gelişmesi; sağlık kültürünün gelişmesi, kaynakların doğru kullanılması ve bireyin hem kendi sağlığı hem de toplum sağlığı açısından önemlidir. Birinci basamağı etkin kullanmak ve sevk sistemini etkinleştirmek daha sağlıklı ve sorunsuz bir sistemin oluşmasına neden olacaktır. Hastane poliklinik randevularının kısa sürede verilmesi için ihtiyaç olan uzman doktor sayısı arttırılmalıdır. Acil servis benzeri 7/24 çalışan genel poliklinik hizmetinin verilebileceği sistem üzerinde çalışılmasının faydalı olacağını düşünmekteyiz.

\section{Çıkar çakışması beyanı}

Yazarlar bu yazının hazırlanması ve yayınlanması aşamasında herhangi bir çıkar çakışması olmadığını beyan etmişlerdir.

\section{Finansman}

Yazarlar bu yazının araştırma ve yazarlık sürecinde herhangi bir finansal destek almadıklarını beyan etmişlerdir.

Yazarların Katkıları: Fikir/Kavram: Z.G.; Tasarım: Z.G.; Veri Toplama ve/veya İşleme: Z.G., Ş.C.; Analiz ve/veya Yorum: Ş.C.; Literatür Taraması: H.S., Z.G.; Makale Yazımı: H.S., Z.G., Ş.C.; Eleştirel İnceleme: H.S., Z.G., Ş.C.

\section{KAYNAKLAR}

1. ifem.cc [Internet]. The International Federation for Emergency Medicine. Melbourne: Carol Reardon Executive Officer International Federation for Emergency Medicine; 1989-01 [Updated: 2020 Jul 1; Cited: 2002 Jul 8]. Available from: https://www.ifem.cc.

2. Eryılmaz M. Ülkemizde acil sağlık hizmetleri: İhtiyaca yönelik güncel çözüm önerileri. Turkish Journal of Trauma \& Emergency Surgery. 2007; 13(1) : 4-12.

3. Ersel M, Karcıoğlu Ö, Yanturalı S, Yürüktümen A, Sever M, Tunç MA. Bir acil servisin kullanım özellikleri ve başvuran hastaların aciliyetinin hekim ve hasta açısından değerlendirilmesi. Turkish Journal of Emergency Medicine. 2006; 6(1): 25-35.

4. Slankamenac K, Zehnder M, Langner TO, Krähenmann K, Keller DI. Recurrent emergency department users: two categories with different risk profiles. J Clin Med. 2019; 8(3): 333.

5. Oktay C, Cete Y, Eray O, Pekdemir M, Günerli A. Appropriateness of emergency department visits in a Turkish university hospital. Croatian Medical Journal. 2003; 44(5): 585-91.

6. Grover CA, Crawford E, Close RJ. The efficacy of case management on emergency department frequent users: An eight-year observational study. J Emerg Med. 2016; 51(5): 595-604.
7. Aydın T, Aydın ŞA, Köksal Ö, Özdemir F, Kulaç S, Bulut M. Uludağ Üniversitesi Tıp Fakültesi hastanesi acil servisine başvuran hastaların özelliklerinin ve acil servis çalışmalarının değerlendirilmesi. Akademik Acil Tıp Dergisi. 2010; 9(4): 163-8.

8. Pereira S, Oliveira Silva A, Quintas M, Almeida J, Marujo C, Pizarro M, et al. Appropriateness of emergency department visits in a Portuguese university hospital. Ann Emerg Med. 2001; 37(6): 580-6.

9. Sönmez CI, Başer DA, Uludağ G, Kara H, Peker A, Taşkaya $\mathrm{K}$ ve ark. Düzce Üniversitesi aile hekimliği polikliniğine başvuran erişkin hastaların acile başvurma nedenleri ve iliş̧kili faktörler. Konuralp Tıp Dergisi. 2019; 11(2): 195-201.

10. Jerius M, El-Salim A, Tarawneh MD, Habashneh M. Inappropriate utilization of emergency medical services at Prince Ali Military Hospital. Journal of the Royal Medical Services. 2010; 17(2): 32-5.

11. Backman AS, Blomqvist P, Lagerlund M, CarlssonHolm E, Adami J. Characteristics of non-urgent patients: Cross-sectional study of emergency department and primary care patients. Scandinavian Journal of Primary Health Care. 2008; 26(3): 181-7.

12. Kilıçaslan İ, Bozan H, Oktay C, Göksü E. Türkiye'de acil servise başvuran hastaların demografik özellikleri. Türkiye Acil Tıp Dergisi. 2005; 5(1): 513.

13. Sezgin D. Sağlık okuryazarlığını anlamak. Galatasaray Üniversitesi İletişim Dergisi. 2013; (Özel Say1 3): 73-92.

14. Atzema CL, Maclagan LC. The transition of care between emergency department and primary care: A scoping study. Acad Emerg Med. 2017; 24(2): 20115. 